\title{
The Challenges of Collective Action for Olive Growers in Albania
}

Rezear Kolaj

Edmira Ozuni

Faculty of Economics and Agribusiness, "Agricultural University of Tirana"

Dubravka Skunca

Dorjana Zahoalia

Faculty of Business and Industrial Management, "Union-Nikola Tesla" University, Belgrade, Serbia

\begin{abstract}
Despite a considerable increase of surfaces with new olive cultivars during last two decades in Albania, the yields have not followed the expected trend. Participation of farmers in common activities would have benefits for costs cutting and efficiency as well as for the commons in a broader economic and social aspect. An opportunity for reducing costs and increasing farmers' income is the organization of farmer's production by the principles of collective action. The research objective is to find factors affecting the olive growers (farmers) participation in collective actions in Berat area, the second largest olive production area in Albania. A questionnaire was designed in order to measure several variables. Interviewing took place from October 2015 to February 2016. Education, access to markets, income and leadership have statistical significance and influence olive producer's participation in activities based on collective action. The research results can be useful to policymakers, public bodies and researchers. The fact that with farm size increase, decrease the possibility of farmer's participation in collective action activities is important finding that helps in understanding the critical financing limits and optimization of the public funds used in creation of public policies.
\end{abstract}

Keywords: agriculture, farmers, Berat, participation

\section{Introduction}

The olive cultivation represents an important traditional agricultural activity in the rural area of Albania concerning the economic, social and environmental impact. This is particularly evident in hilly and mountain areas, where horticulture in general and olive production are among the major agricultural activities. The fact that Albania has about 300 sunny days and abundant hydropower potential provides another argument that meets typology of this agricultural crop. Olives and derivate products, especially olive oil, represents important category of food products for the diet of Albanian families in terms of nutritious food with significant energy value. On the other hand, the production of olives represents a vital activity with economic interest for farmers involved in growing olives. Olive cultivation is related to the tradition and knowledge of farmers in many agricultural areas. One of the most important areas for olive production in Albania is Berat (Table 1). Farmers in this area are among the most important olive growers on national level. Berat area, which is located in southwest Albania and known for centuries for the traditional olive production, is on second place for the number of cultivars on national level (INSTAT 2015).

Table 1. The number of olive trees by prefectures in Albania, thousand trees

\begin{tabular}{ll}
\hline Prefectures & Olives \\
\hline Berat & 1.679 \\
Fier & 2.193 \\
Vlore & 1.548 \\
\hline
\end{tabular}

Source: INSTAT 2015 
During the last 2 decades, olive cultivation has expanded as the number of planted trees and yields increased (Table 2). Between 1998 and 2014 the number of planted cultivars has been between 3. 468 million and 8. 620 million trees, while production was between 46800 tones and 98000 tones (INSTAT 2015).

Table 2. Number of trees, production and yield of the olive culture over the years in Albania

\begin{tabular}{llllllllll}
\hline Olives & 1998 & 2000 & 2002 & 2004 & 2006 & 2008 & 2010 & 2012 & 2014 \\
\hline $\begin{array}{l}\text { Totally } \\
\text { (thousand } \\
\text { trees) }\end{array}$ & 3.468 & 3.611 & 3.809 & 4.092 & 4.497 & 5.011 & 6.255 & 8.000 & 8.994 \\
$\begin{array}{l}\text { Production } \\
\text { (thousand } \\
\text { tonnes) } \\
\begin{array}{l}\text { Yield } \\
\text { (kg/plant) }\end{array}\end{array}$ & 46.8 & 36.2 & 27.3 & 58.7 & 40.2 & 56.2 & 70 & 108 & 98 \\
\hline
\end{tabular}

Source: INSTAT 2015

Despite the above indicators yields during the same period were more stable - between $14.6 \mathrm{~kg} / \mathrm{trees}$ and $16.9 \mathrm{~kg} / \mathrm{trees}$. A similar trend represents the production of olive oil. Olive production indicators can be justified by the fact that a large proportion of planted young trees have not yet entered the production phase. On the other hand this is explained by rising costs, including input prices over the years, affecting the level and quality of their use by farmers, including agro technical efficiency of operations. A number of chemicals that are used for olive cultivation oblige organization at level group farmers to spray large surfaces for effective protection against diseases and pests. Reducing costs and encouraging positive impact in terms of farmers participation in activities based on the principles of collective action would be a way to overcome this problem. Participation of farmers in common activities would have benefits for costs cutting and efficiency as well as for the commons in a broader economic and social aspect. Organization of farmer's production by the principles of collective action would be an opportunity for reducing costs and increasing farmers' income. Spraying with insecticides and chemicals is important for pest's protection, but marketing, selling of production and the organization at the level of producers is crucial, especially since it is represented in the framework of future integration in the European Union. Structuring based on the functional organization of agricultural producers can serve for buying inputs at low prices as it could give opportunity to use benefits of subsidies, training, new technologies in order to increase production and efficiency in the cultivation of olive trees, all of which in the aim of creating conditions for the increase of farmers income.

A broad framework of the theory of collective action is developed. The first critics of the theory were Bentley and Truman. They believed that individuals with common interests will act voluntarily to achieve these interests (Bentley 1949; Truman 1958). Olson substantially transformed the debate with his new approach that groups will aim to be involved in collective action whenever individuals see benefits (Olson 2002). Moreover, whether appropriate instruments will enable the individuals to manage resources, they will tend to respect and follow the rules (Larson and Ribot 2004). Researchers have agreed that the characteristics of resources are affecting tendencies of individuals to participate in the organizations (Ostrom et al. 1994; Araral 2009). Ostrom and Ahn believe that economic performance in rural communities critically depends on how community members solve problems of collective action. The approach to social capital links the causes and results of collective social behavior (Ostrom and Ahn 2007). Krishna supports the view that in groups of producers there is more disagreement with increasing and strengthening of social capital and that this can contribute to formalize solutions and overcoming differences between members (Krishna 2004).

Banaszak investigates determinants of successful cooperation in agricultural markets and finds that variables such as social capital, power of leadership and previous knowledge in the field of business are crucial regarding the opportunities for success in organizations included in the study (Banaszak 2008). Meinzen-Dick, Raju and Gulati found that organizations with highly educated and influential leaders are more likely to be formed faster and to have more significance (MeinzenDick et al. 2002). Krishna believes that the quality of leadership influence the effectiveness of employees to the degree to which members can be involved in collective actions (Krishna 2004).

Considering the discouraging experience of the models of cooperation during communism period and the lack of incentive programs for collective action in the post-communist period, the farmer community in Albania still has a tendency for the relatively low participation in collective actions. There is empirical evidence concerning the lack of collective action in 
Albania. Leonetti was expressing skepticism if Albania can have farmers organizations formalized as functional level farmers groups (Leonetti 2009). Situation has changed due to increased production and access to the markets through the years. Skreli and Musabelliu have researched the problem of collective action in Albania (Skreli 1994; Musabelliu 1997). Skreli, Kola and Osmani (2011) were evidencing the importance of leadership and found that the perception of a capable and credible leader particularly affects opportunities of farmers who are apple producers to participate in collective action (Skreli et al 2011). Kola, Skreli, Osmani and Tanku found that there is strong influence of social capital (trainings), human capital, leadership and supply of inputs on collective action (Kola et al. 2014).

\section{MATERIALS AND METHODS}

The study has objective to investigate determinants that affect the opportunities for collective action of olive producers (farmers) in one of the main agricultural production areas in Berat in southwest of Albania. In order to achieve the goal hypotheses have been designed (Table 3). Determinants shown in the table (Table 3) will be measured by the perception of farmers.

Table 3. Determinants of collective action

\begin{tabular}{ll}
\hline Determinants of collective action & Hypotheses \\
\hline Social Capital & $\begin{array}{l}\text { With increase of social capital stock the possibilities for collective } \\
\text { action are increasing } \\
\text { With increase of wealth the possibilities for collective action are } \\
\text { increasing } \\
\text { With increase of level of education the possibilities for collective } \\
\text { Education }\end{array}$ \\
$\begin{array}{l}\text { action are increasing } \\
\text { With increase of farmers perception for leadership the } \\
\text { possibilities for collective action are increasing }\end{array}$ \\
\hline
\end{tabular}

Source: Own elaboration

The questionnaire has been created to provide the data and measure a number of variables. Data were collected through a survey that included separate interviews with 220 farmers (Table 4), which was sufficient to provide a confidence level of 95\% (Israel 2012). The method of choice is based on a random choice. The data has been subjected to the verification of preciseness.

Table 4. Socio-demographic profile of the sample ( $N=220$, frequency, percentage in brackets)

\begin{tabular}{lllllllll}
\hline Country & & Gender & \multicolumn{3}{c}{ Age (years) } \\
& $\mathrm{N}(\%)$ & Female & Male & $\leq 24$ & $25-34$ & $35-49$ & $50-64$ & $\geq 65$ \\
\hline \multirow{2}{*}{ Albania } & 220 & 13 & $207(94$. & & & $80(36$. & $113(51$. & \\
& $(100)$ & $(5.9)$ & $1)$ & $1(0.5)$ & $10(4.5)$ & $4)$ & $4)$ & $16(7.3)$ \\
\hline
\end{tabular}

Source: Own calculations

Model was determined after the data were collected and measured. In order to measure hypotheses determinants, method of measurement and the respective symbols are presented:

$Y=$ whenever people have collaborated (channel maintenance, livestock preservation, road construction) they have come up with benefit (binary variable; $\mathrm{No}=0$, Yes $=1$ );

$\mathrm{X} 1=$ education (categorical variable measured by scale of $1=$ no elementary school, $9=$ higher education);

$\mathrm{X} 2=$ wealth based on the number of olives (quantitative variable);

$\mathrm{X} 3=$ training for cooperation (binary variable; No $=0$, Yes $=1$ );

$\mathrm{X} 4=$ institutions as perceived by the farmer concerning functioning of the market (categorical variable measured with scale from 1 to $5: 1$ = totally disagree, 5 = strongly agree);

$X 5=$ the level of income (quantitative variable);

$X 6=$ leadership (binary variable; $\mathrm{N}_{0}=0$, Yes $=1$ );

X7 = participation in activities (social capital).

In order to measure the degree of participation in social activities the data were organized as follows: 
$1=$ None;

$2=$ (Group of parents, school committee, sports groups, other);

$3=$ (Religious group, cultural association, political group, youth group, women's group);

4 = (Savings and credit association, irrigation association, informal quarter union (or village), civil association - free engagement, non-governmental association);

$5=$ (Farmer group, trade associations, group of businesses, professional associations, syndicates) .

Since the dependent variable is a dummy qualitative variable, for evaluation of the determinants the binary logistic regression model was used. Binary logistic model has the following form:

$$
\ln \left(\frac{P_{i}}{1-P_{i}}\right)=\beta_{0}+\beta_{1} \cdot x_{i 1}+\beta_{2} \cdot x_{i 2}+\ldots+\beta_{k} \cdot x_{i k}+e
$$

Where $P_{i}$ is the probability that farmer $i$ finds interest in participation in collective action as a profit opportunity; $1-P_{i}$ represents probability that the farmer do not find interest in participation in a collective action as a profit opportunity; $x_{i}$ represents respective variables concerning the characteristics of the individual players and their perception; and $\beta_{i}$ represents parameters that are going to be measured. Equation is given in the form:

$$
\frac{P_{i}}{1-P_{i}}=e^{\hat{\rho}_{0}+\hat{f}_{1} \cdot \mathbf{z}_{i 1}+\hat{f}_{2} \cdot \mathbf{z}_{i 2}+\ldots+\hat{f}_{i} \cdot \mathbf{z}_{i \mathbf{i}}+e}
$$

And the probability is:

$$
P_{i}=\frac{e^{\beta_{0}+\beta_{1} \cdot x_{i 1}+\ldots+\beta_{k} \cdot x_{i k}+e}}{1+e^{\beta_{0}+\beta_{1} \cdot x_{i 1}+\ldots+\beta_{k} \cdot x_{i k}+e}}
$$

\section{RESULTS AND DISCUSSION}

For obtaining the results SPSS program was used and forward Wald method was chosen because more variables were included in the model. The program stopped in the step number 7 (Table 5) and the variables that had significant results by a level of importance $10 \%$ are shown in Table 6 .

Table 5. Model indicators

\begin{tabular}{llll}
\hline \multicolumn{2}{l}{ Model Summary } & & \\
\hline Step & -2 Log likelihood & Cox \& Snell R Square & Nagelkerke R Square \\
\hline 7 & $102.853^{\mathrm{b}}$ & .541 & .725 \\
\hline
\end{tabular}

\begin{tabular}{|c|c|c|c|c|c|c|c|}
\hline \multicolumn{8}{|c|}{ Variables in the Equation } \\
\hline & & B & S. E. & Wald & $\mathrm{df}$ & Sig. & $\operatorname{Exp}(B)$ \\
\hline \multirow{8}{*}{ Step $7 g$} & Educ. & .299 & .144 & 4.310 & 1 & $.038^{* *}$ & 1.349 \\
\hline & Nr_olives & -.004 & .002 & 3. 023 & 1 & $.082^{*}$ & .996 \\
\hline & Training_coop. & 1. 918 & 1. 013 & 3.585 & 1 & $.058^{*}$ & 6.809 \\
\hline & Market_funct. & 1. 116 & .286 & 15. 248 & 1 & $.000^{\star * *}$ & 3. 052 \\
\hline & Incomes & .502 & .140 & 12. 868 & 1 & $.000^{\star \star *}$ & 1.653 \\
\hline & Group_leader & 4. 266 & .816 & 27. 317 & 1 & $.000^{\star \star *}$ & 71. 213 \\
\hline & Particip. in activities & .297 & .173 & 2. 960 & 1 & $.085^{\star}$ & 1. 346 \\
\hline & Constant & -10.970 & 2. 675 & 16. 812 & 1 & $.000^{\star * *}$ & .000 \\
\hline
\end{tabular}

Source: Own calculations

Table 6. Statistically significant variables 
* significant for the level of importance 0.10

** significant for the level of importance 0.05

*** significant for the level of importance 0.001

Source: Own calculations

Model results show that the measured variables have a positive impact for increasing the possibilities for cooperation as an instrument that increase farmer profits. In the case of farm size this impact is negative, meaning that with increase of farm size decreases the possibility that cooperation would be used as a tool for profit increasing. This finding represents an important element in the research concerning the large farms, because farmers do not see the cooperation as an opportunity they could benefit from. Another crucial result of the research is very high impact that leadership (measured as Group_leader) has as an opportunity for participation of farmers who are olive growers in co-organizations based on the principles of collective action. In this case, the farmer's possibility to see it as an opportunity for cooperation is 71.213 times higher than not to see it as such opportunity.

\section{Conclusion}

The research has achieved the goal by enabling an analytical presentation of the factors that affect the opportunities for increasing the cooperation between farmers who are olive growers in Berat area in the southwest of Albania. The findings of the research are confirming hypothesis and they are in line with previous studies. The results can be useful to interested policymakers, public bodies and researchers who are offering a framework of knowledge concerning opportunities for reducing costs and increasing income for farmers who are olive growers as well for the general agricultural and regional development. From a theoretical perspective the study supports findings that the size of the farm and trust in leadership affect the farmers' perception and their behavior to participate in the collective action activities. The results can serve as a theoretical basis for future research in this area.

The impact of education (measured as educ. ) is important for the participation of farmers in functional activities according to the principles of collective action. This finding supports a broad theoretical framework. The negative impact of farm wealth (measured as nr_olives), also represents an important finding. The fact that with increase of farm size decreases the potential for collective action is not a surprise. In previous studies on collective action similar evidences have indicated that the readiness of farmers for collective action differ not only for different activities (apple growers, vegetable growers in greenhouses), but it can also differ within the same activity concerning the size of the farm (Skreli et al. 2011; Kola et al. 2014). This evidence requires attention, especially from policymakers and public bodies that finance agriculture, in order to understand the limits of financing and for finding the balance that optimize the efficiency of public funds used in the case of policies or increasing incentives efficiency. Meanwhile, increased importance of the leadership role represents a crucial factor for farmers. The role of competent leadership concerning complicated agricultural issues of production and marketing is very important for increasing of trust and cooperation between stakeholders in rural community.

\section{REFERENCES}

[1] Araral E. (2009): The strategic games that donors and bureaucrats play: An empirical rational choice analysis. Journal of Public Administration, Research and Theory, 19: 853-871.

[2] Banaszak I. (2008): Determinants of successful cooperation in agricultural markets: evidence from producers groups in Poland. Strategy and Governance of Networks, 1:27-46.

[3] Bentley A. (1949): The Process of Government: A Study of Social Pressures. Principia Press of Illinois, Illinois.

[4] INSTAT (2015): Statistical Yearbook, 2010-2014. Available at http://www. instat. gov. al/media/318992/statistical_yeasrbook_2014. pdf (accessed Oct 20, 2016).

[5] Israel G. D. (2012): Determining Sample Size. Available at http://www. psycholosphere. com/Determining\%20sample\%20size\%20by\%20Glen\%20lsrael. pdf (accessed Oct 10, 2016).

[6] Kola R., Skreli E., Osmani M., Tanku A. (2014): Farmers' characteristics as determinants of collective action: the case of Greenhouse Producers in Albania. New Medit, 13: 20-27. 
[7] Krishna A. (2004): Understanding, measuring and utilizing social capital: clarifying concepts and presenting a field application from India. Agricultural Systems, 82: 291-305.

[8] Larson A. M., Ribot J. C. (2004): Democratic decentralization through a natural resource lens: An introduction. European Journal of Development Research, 16: 1-25.

[9] Leonetti L. (2009): Research study. FAO, Budapest.

[10] Meinzen-Dick R., Raju K. V., Gulati A. (2002): What affects organization and collective action for managing resources? Evidence from canal irrigation systems in India. World Development, 30: 649-666.

[11] Musabelliu B. (1997): Family farms and the alternatives of cooperation in Albanian agriculture, Institute of Economy, Finance and Business, Tirana.

[12] Olson M. (2002): The Logic of Collective Action: Public Goods and the Theory of Groups. 20 th Ed. Harvard University Press, Cambridge.

[13] Ostrom E., Ahn, T. K. (2007): The meaning of social capital and its link to collective action. Available at https://papers. ssrn. com/sol3/papers. cfm?abstract_id=1304823 (accessed Aug 25, 2016).

[14] Ostrom E., Gardner R., Walker J. (1994): Rules, Games, and Common-Pool Resources. University of Michigan Press, Michigan.

[15] Skreli E. (1994): La Place Future de la Formule Associative au Niveau de la Production Agricole en Albanie. University of Cukorova, Adana.

[16] Skreli E., Kola R., Osmani M. (2011): Factors determining collective action in Albanian agriculture: case of apple producers in Albania. Albanian Journal of Agricultural Sciences, 10: 35-41.

[17] Truman D. B. (1958): The Governmental Process. Knopf, New York 